\title{
Embryonically induced $\beta$-catenin haploinsufficiency attenuates postnatal heart development and causes violation of foetal genes program
}

\author{
O. L. Palchevska ${ }^{1,2}$, V. V. Balatskii ${ }^{1,2}$, A. O. Andrejeva ${ }^{1,2}$, L. L. Macewicz ${ }^{1}$, \\ O. O. Piven ${ }^{1}$, L. L. Lukash ${ }^{1}$ \\ ${ }^{1}$ Institute of Molecular Biology and Genetic, NAS of Ukraine \\ 150, Akademika Zabolotnogo Str., Kyiv, Ukraine, 03680 \\ ${ }^{2}$ ESC «Institute of Biology», Taras Shevchenko National University of Kyiv \\ 64/13, Volodymyrska Str., Kyiv, Ukraine, 01601 \\ o.o.piven@imbg.org.ua
}

\begin{abstract}
The $\beta$-catenin role in myocardium remodeling and hypertrophy development is the subject of numerous and controversial investigations. Aim. To investigate the significance of cardiac ablation of $\beta$-catenin for heart development using conditional knockout approach. Methods. Standard histological techniques (HE- and MT-staining) and quantitative RT-PCR were used. Results. Our data demonstrate that $\beta$-catenin haploinsufficiency in heart provokes upregulation of foetal genes program without visible morphological abnormalities comparing to control groups of animals of the same age. Conclusions. Our data demonstrate that experimental conditions in this study provoke the delay in the development and growth of adult heart without visible morphological abnormalities.
\end{abstract}

Keywords: heart development, $\beta$-catenin, Wnt-signaling, heart remodeling, hypertrophic response.

Introduction. The adult heart is a dynamic organ capable of significant remodeling and hypertrophic growth for adaptation to altered workloads or injury. Hemodynamic stress or neuroendocrine signaling associated with myocardial infarction, hypertension, aortic stenosis, and valvular dysfunction evoke a pathologic remodeling response through the activation of intracellular signaling pathways and transcriptional mediators in cardiac myocytes [1]. Activation of these molecular pathways may initially augment cardiac output (adaptive hypertrophy), however, prolonged hypertrophy (pathological or maladaptive hypertrophy) leads to heart failure and sudden cardiac death (SCD). Whilst there have been major advances in the identification of genes and signaling pathways involved in mediating hypertrophy it is clear that due to the overall complexity of hypertro-

(C) Institute of Molecular Biology and Genetics, NAS of Ukraine, 2013 phic remodeling further characterization of the underlying molecular mechanisms is needed.

One such signaling pathway that plays a major role in both heart development and normal heart homeostasis is the Wnt/ $\beta$-catenin pathway [2-7]. Beta-catenin is an armadillo protein family member and has dual function forming an essential component of the adherent junction mediating cell-cell contact and acting as a transcriptional co-activator of the T-cell factor/lymphoid enhancer factor (TCF/LEF) complex [8-10]. During cardiogenesis, Wnt/ß-catenin activity displays a biphasic role as it appears to be required for cardiac progenitor cell (CPC) specification and expansion during early development but needs to be fine-tuned at later stages to allow terminal differentiation [11-13].

Conditional inactivation of $\beta$-catenin in endothelial cells prevents endothelial-mesenchymal transformation during cardiac development [4]. A number of experimen- 
tal works demonstrated that loss of $\beta$-catenin at early stages of heart formation using different tissue-specific promoters led to multiple embryonic heart malformation and had lethal effect [14-16]. Meanwhile, conditional knockout of $\beta$-catenin after first and second heart field formation does not lead to early embryonic death, possibly due to functional redundancy between $\beta$-catenin and plakoglobin ( $\gamma$-catenin), but leads to lethality of late embryos and newborn mice [17, 18]. Interestingly, $\gamma$-catenin is a close relative of $\beta$-catenin [19] but in contrast to $\beta$-catenin it can interact with both classical cadherins in AJs and desmosomal cadherins in desmosomes. It was shown that ablation of $\beta$-catenin in the adult heart does not result in lethality or other morphological heart malformations, presumably due to compensation by plakoglobin [20]. Consistently, it was shown that cardiac-specific deletion of both $\gamma$-catenin and $\beta$-catenin in adult heart leads to cardiomyopathy resulting in SCD [21]. It has been demonstrated that activation of $\beta$-catenin is not only sufficient but also required to induce cardiomyocyte hypertrophy, and interestingly, the activation of $\beta$-catenin can occur independently of Wnt stimulation $[22,23]$. The importance of $\beta$-catenin-dependent signaling for the development of cardiac hypertrophy has also been confirmed in vivo using mice with conditional cardiac-specific knockout of $\beta$-catenin [24]. Cardiac-specific haploinsufficiency of $\beta$-catenin attenuates pressure-overload-induced cardiac hypertrophy after transverse aortic constriction (TAC) [18] while overexpression of a constitutively active form of $\beta$-catenin results in dilated cardiomyopathy [25].

In another study by Hahn et al. [26] the overexpression of a constitutively active form of $\beta$-catenin led to spontaneous hypertrophy of cardiomyocytes in culture. However, the role of $\beta$-catenin during heart reconstruction is still unclear with some investigations demonstrating opposing results. For example, it was reported that $\beta$-catenin downregulation was necessary for adaptive cardiac remodeling and cardiac hypertrophy development [27].

In this study we have addressed the role of $\beta$-catenin during postnatal heart development and remodeling. For this purpose we induced embryonic $\beta$-catenin haploinsufficiency in heart using Cre-mediated technique. We have analyzed the heart morphology and physiological hypertrophic remodeling of mice at different time points (1, 3 and 6 month) under $\beta$-catenin haploinsufficiency conditions and in normal animals in vivo.

Materials and methods. Generation of mutant mice. To generate cardiac-specific deletion of $\beta$-catenin $\beta$-cat ${ }^{\text {flox } /+}, \alpha$-myosin heavy chain $(\alpha-M H C)$-Cre mice were mated with $\beta$-cat ${ }^{\text {flox flox }}$ mice. The mice with heterozygous floxed $\beta$-cat, $\alpha-M H C$-Cre transgene were designated as mutants and were used for the analysis, the mice of all other genotypes served as controls. Alfa $\mathrm{MHC}$-Cre transgene elicited recombination in cardiac muscles, but not other organs [28, 29]. Male mice were used in all experiments.

Homozygous conditional $\beta$-catenin ${ }^{\text {flox flox }}$ mice and $\alpha$-MHC-Cre mice were kindly provided by Dr. G. L. Radice (Jefferson Medical College, USA).

Mice genotyping. DNA isolation and PCR analysis were carried out according to standard protocols [30]. The following primer sets were used to discriminate floxed, mutant and wild type $\beta$-catenin alleles: 5'-AGGTA GAGTGATGAAAGTTGTT-3' and 5'-CACCATGTC CTCTGTCTATTC-3'; $\alpha$-MHC-Cre transgene was identified with primers 5'-CAGAACCTGAAGATGTTCG C-3' and 5'-TACACCTCGGTGCTA ACCAG-3'.

Histological analysis. Hearts were isolated and fixed in $4 \%$ paraformaldehyde, dehydrated, and embedded in paraffin [30]. Global heart architecture was determined from longitudinal $9-\mu \mathrm{m}$ deparaffinized sections stained with hematoxylin and eosin (H\&E). Tissue fibrosis was detected with Masson's trichrome (MT) stain. Cross-sectional heart area was analyzed using light microscopy Primo Star («Carl Zeiss», Austria).

$R N A$ isolation, reverse transcription, and $q P C R$. Total RNA was isolated from ventricular heart tissue using UltraClean Tissue \& Cells RNA Isolation Kit (MO BIO) according to the manufacturer's protocol. cDNA was synthesized using the First Strand cDNA Synthesis Kit («Fermentas», Lithuania) with DNAse I treatment step, and PCR was performed with Maxima SYBR Green/Fluorescein qPCR Master Mix («Fermentas») in the iCycler single-color real-time PCR detection system (IQ5, «BioRad», USA). Gene expression was represented by the $\Delta \mathrm{C}_{\mathrm{T}}$ value normalized to the reference gene for glyceraldehyde 3-phosphate dehydrogenase (GAPDH). The $\Delta \Delta \mathrm{C}_{\mathrm{T}}$ value of each target gene was then calculated by subtraction of the average $\Delta \mathrm{C}_{\mathrm{T}}$ from the control group. Finally, the $n$-fold difference was 
calculated by using the formula $2 \Delta \Delta^{\mathrm{CT}}$. Data from 2 to 4 heart samples were collected and analyzed in duplicate. The primers used for qPCR were for atrial natriuretic protein (ANP; forward - 5'-CATCACCCTGGGCTTC TTCCT-3'; reverse - 5'-TGGGCTCCAATCCTGTC AATC-3'), brain natriuretic protein (BNP; forward 5'-GCGGCATGGATCTCCTGAAGG-3'; reverse - 5'CCCAGGCAGAGTCAGAAACTG-3'), $\beta$-MHC (forward - 5'-ATGTGCCGGACCTTGGAA-3'; reverse 5'-CCTCGGGTTAGCTGAGAGATCA-3'), $\alpha$-MHC (forward - 5'-GGCACAGAAACACCTGAAGA-3'; reverse - 5'-CATTGGCATGGACAGCATCATC-3'), and GAPDH (forward - 5'-CCACTCTTCCACCTTC GATG-3'; reverse - 5'-TCCACCACCCTGTTGCTGT A-3').

Results and discussion. Embryonically induced $\beta$ catenin haploinsufficiency in heart did not lead to lethality but affected postnatal heart development. As we reported earlier [17] cardiospecific ablation of $\beta$-catenin at early embryonic stages leads to lethality at late gestation. In present study we focused on the analysis of the embryonical ablation of $\beta$-catenin on postnatal heart development. We studied how $\beta$-catenin haploinsufficiency condition is reflected on postnatal heart development and growth. We generated $\beta$-cat-CKO mice as described earlier [17]. Mice were sacrificed at 1, 3 and 6 month of age. For evaluation of adult heart hypertrophy response the HW/BW index was calculated. We did not find any significant differences between HW/BW index of WT and $\beta$-catenin haploinsufficient mice at one month of age (1-month-old mice) (Fig. 1). When analyzing older mice ( 3 and 6 month of age) we observed some changes in mutant mice group as shown in Fig. 1. At three month of age $\beta$-catenin haploinsufficient mice had lower HW/BW ratio as compared to wild type. With ageing (6 month) we revealed only a tendency to increase the HW/BW ratio in mutant group (Fig. 1).

These data suggested that $\beta$-catenin haploinsufficiency provoked a delay in the development and growth of the adult heart (via the effect ANP and BNP on myocardium) probably with following hypertrophic responses development during ageing as a result of secondary compensatory effect.

Beta-catenin haploinsufficiency didn't lead to morphological malformations and heart tissue fibrosis. Despite the age-related changes in $\mathrm{HW} / \mathrm{BW}$ ratio the heart

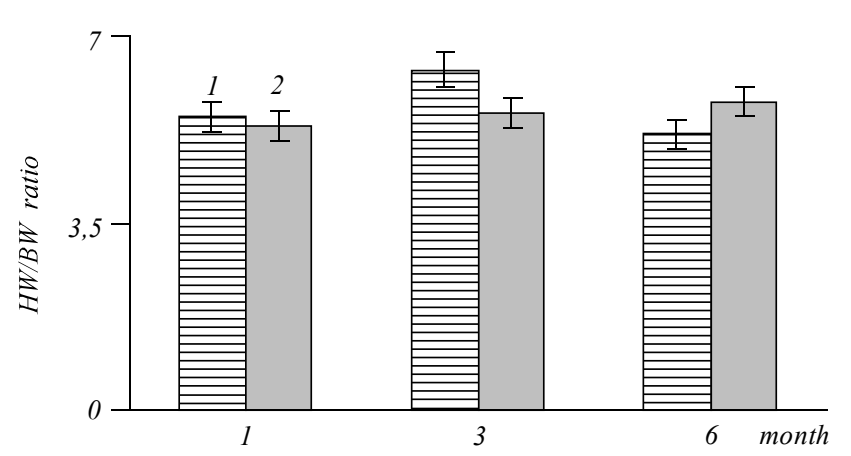

Fig. 1. Analysis of control (1) and mutant (2) mice heart development of different ageing groups. Quantification of heart weight/body weight ratios of $\beta$-catenin flox $/ \mathrm{wt} / \mathrm{Cre}^{+}$and WT mice at 1,3 and 6 months were performed. Note WT $n \geq 30$, CKO $n \geq 15$ in each group

tissue morphological analysis of wild type and $\beta$-catenin haploinsufficient mice did not reveal any difference (Fig. 2, see inset). HE stained heart sections of mice with genotype $\alpha-M H C-C r e^{+}, \beta$-catenin ${ }^{\text {flox }}{ }^{\prime w t}$ looked normally: we have not observed any clearly marked tissue malformations in all analyzed groups (data not showed). Additionally we did not observe tissue fibrosis of control and $\beta$-catenin haploinsufficient hearts in any of analyzed age- ing groups (Fig. 2, see inset).

Probably, $\beta$-catenin haploinsufficiency in heart does not change tissue architecture in analyzed groups of animals due to the functional redundancy between $\beta$-catenin and plakoglobin, taking into consideration that plakoglobin is capable to maintain adherent junction.

Beta-catenin deficiency in adult heart led to upregulation of hypertrophy response genes in age-dependent manner. We have analyzed the level of hypertrophic response genes ( $A N P, B N P, \beta-M H C$ and $\alpha-M H C)$ expression in WT and experimental groups of mice at 1, 3 and 6 month of age. It is well-known that overexpression of $A N P, B N P, \beta-M H C$ genes and $\alpha-M H C$ gene downregulation are associated with heart hypertrophic remodeling. Here we compared how $\beta$-catenin haploinsufficiency in heart affected these specific genes expression in different ageing groups.

Using qPCR we have revealed that hypertrophic genes programs were upregulated at 1 and 3 month of age (Fig. 3, 4) under $\beta$-catenin haploinsufficiency conditions comparing with control groups of animals of the same age.

Notably in both age groups of mutant mice the $\alpha$ $M H C$ gene expression was lower comparing with cont- 
Figure 2 to article by O. L. Palchevska et al.
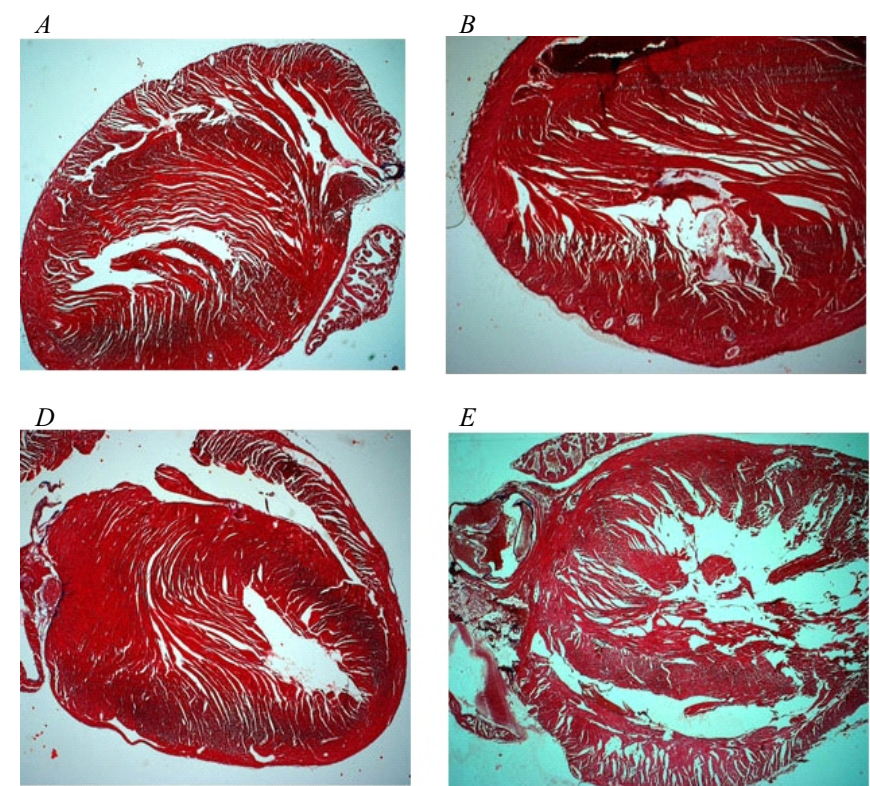
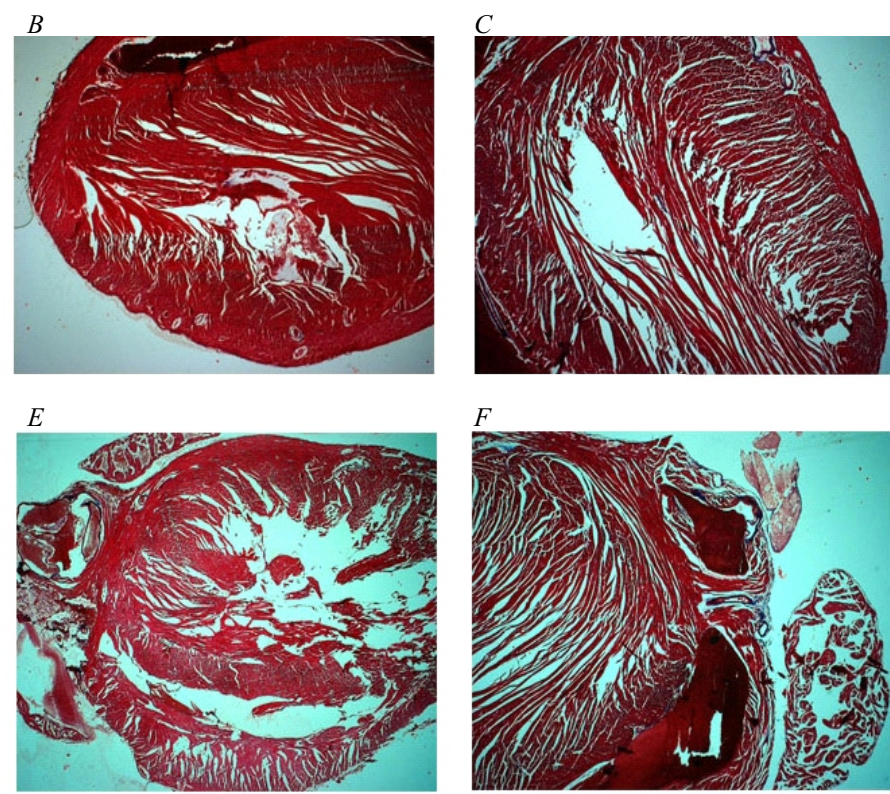

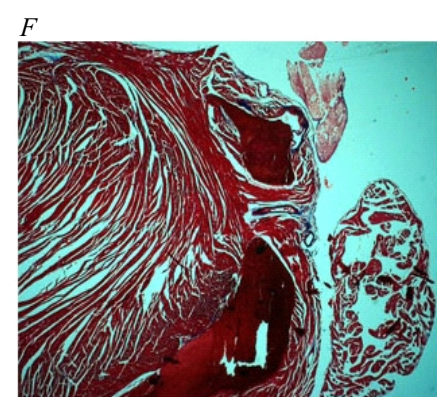

Fig. 2. Histological analysis of the $\beta$-catenin haploinsufficient mice. Longitudial heart sections from $\beta$-catenin flox/ WT/Cre ${ }^{+}$(CKO) and $\beta$-catenin flox/flox/ $\mathrm{Cre}^{-}(\mathrm{WT})$ or $\beta$-catenin flox/ WT/Cre ${ }^{-}$(WT) were stained using Masson's trichrome method. Analyzed mice at 1 $(A, D), 3(B, E)$ and $6(C, F)$ months of age; WT $(A-C)$, $\mathrm{CKO}(D-F) ; \times 4$

Figure 2 to article by $O$. V. Dergai et al.
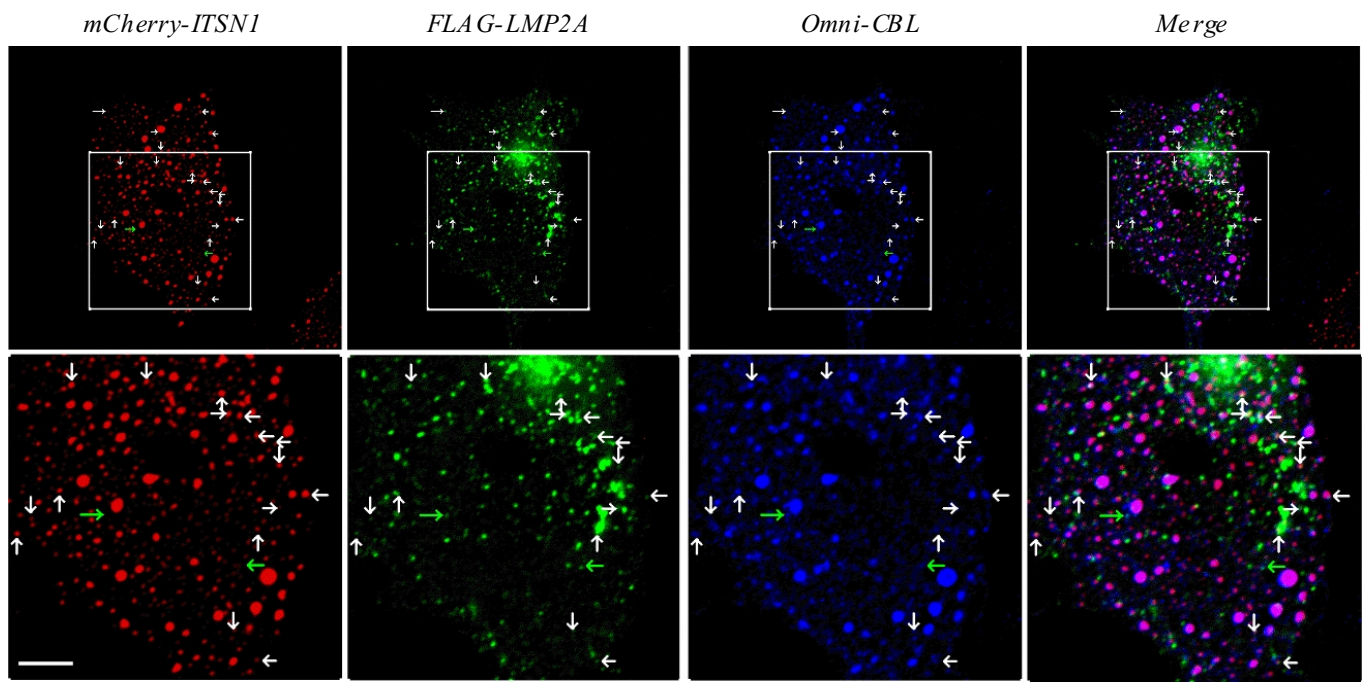

Colocalization
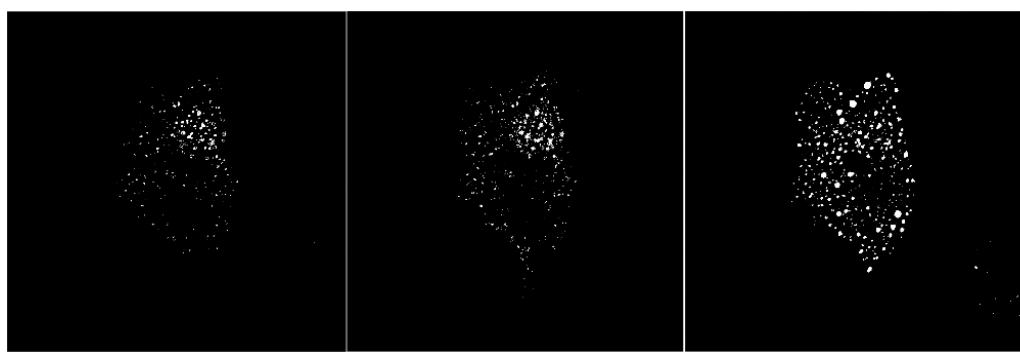

$L M P 2 A$ vS ITSN1

$C B L$ vs $L M P 2 A$

CBL vs ITSN1

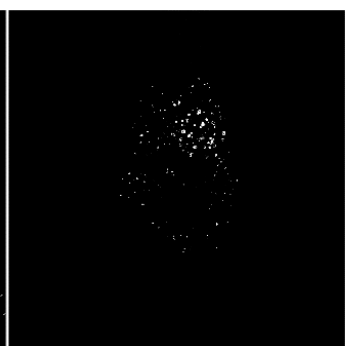

$L M P 2 A+I T S N 1$ vs $L M P 2 A+C B L$
Fig. 2. ITSN1, CBL and LMP2A are colocalized in MCF-7 cells. Cells plated on coverslips were co-transfected with mCherryITSN1, FLAG-LMP2A and Omni-HA-CBL. 24 h posttransfection cells were fixed and processed as described in Material and methods. White arrows highlight examples of triple colocalization, green ones indicate spots of CBL and LMP2A overlapping that are ITSN1 negative. Lower panel represents colocalization of indicated proteins that was obtained from confocal images using ImageJ software. White scale bar represents $5 \mu \mathrm{m}$ 

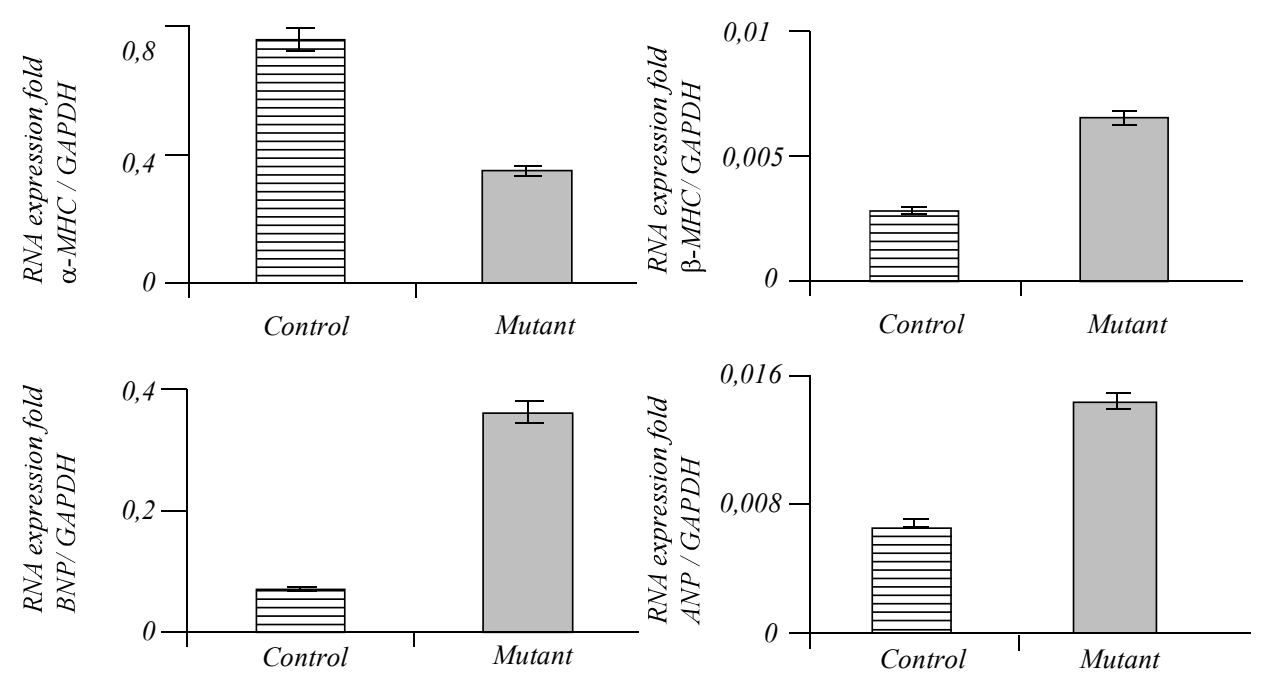

Fig. 3. The hypertrophic response genes expression in $\beta$ catenin haploinsufficient versus WT mice at 1 month of age. Each group consists of 2 mice

rol mice at 1 and 3 months of age. Upregulation the foetal group of genes ( $A N P, B N P$ and $\beta-M H C)$ and $\alpha-M H C$ gene downregulation demonstrated in this study possible means that adult heart under $\beta$-catenin deficiency conditions on molecular level is closer to embryonic or heart under hypertrophic stimulation then to normal adult.

Analyzing the hypertrophic genes expression for six months old heart we revealed that expression of ANP and BNP genes was lower (Fig. 5) in $\beta$-catenin deficient mice comparing to control animals of the same age (Fig. 5) and to mice of 1 and 3 months old (Fig. 3, 4).

In contrast to previously studied age groups, in six month age mice the level of expression of $\alpha-M H C$ gene was higher under $\beta$-catenin haploinsufficiency conditions than in WT animals. But $\beta-M H C$ expression level remained at elevated level similarly to previous age groups.

From our data we can conclude that cardiospecific induction of $\beta$-catenin haploinsufficiency in mice embryos leads to hypertrophy genes upregulation at 1 and 3 month of age with following downregulation of some of them (ANP and $B N P$ ) in older mice (6 month).

We would like to note that in wild type mice the expression of $\beta-\mathrm{MHC}$ is turned off shortly after birth, expression of $\alpha-M H C$ gene in the ventricular myocardium is upregulated and this protein isoform remains to be predominant in adults [28,31]. With aging and during cardiac hypertrophy and failure, $\alpha-M H C$ expression is downregulated [32-34]. Thus, expression of $\alpha-M H C$ gene is altered in a variety of physiological and disease states. The fact that $\beta-M H C$ gene expressed in all studied $\beta$-catenin haploinsufficient groups at higher level comparing with control mice is the evidence that typical healthy adult heart genes program is disrupted.

The signaling and structural functions of $\beta$-catenin in embryos and adult heart development are being studied by different groups of scientists. Meanwhile, the role of $\beta$-catenin during adult heart reconstruction (heart hypertrophy or heart adaptation to ageing and training) is still unclear, even more, some studies demonstrated controversial data.

In present work we generated mice with cardiospecific $\beta$-catenin deficiency and analyzed how this condition contributes to postnatal heart development and adult heart formation. Our data demonstrate that $\beta$-catenin haploinsufficiency in heart provokes the delay in the development and growth of the adult mice heart (at 3 month of age) but without any morphological abnormalities comparing with control groups of animals of the same age. On the other hand we observed that $\beta$-catenin haploinsufficiency leads to hypertrophic response genes upregulation at 1 and 3 month of age. These findings suggest that the reactivation of the foetal gene program is not always linked with hypertrophic growth. This observation is consistent with Dr. F. Li group results [18]. These authors induced cardiospecific ablation of one $\beta$-catenin gene allele but in adult mice (3-4 month of age). As a result they observed that $\beta$-catenin haploinsufficiency attenuated heart hypertrophy but enhanced the foetal genes expression after TAC [18]. Given this the survey of gene expression (genes of hypertrophic response as well as other cardiac Wnt-responsive 

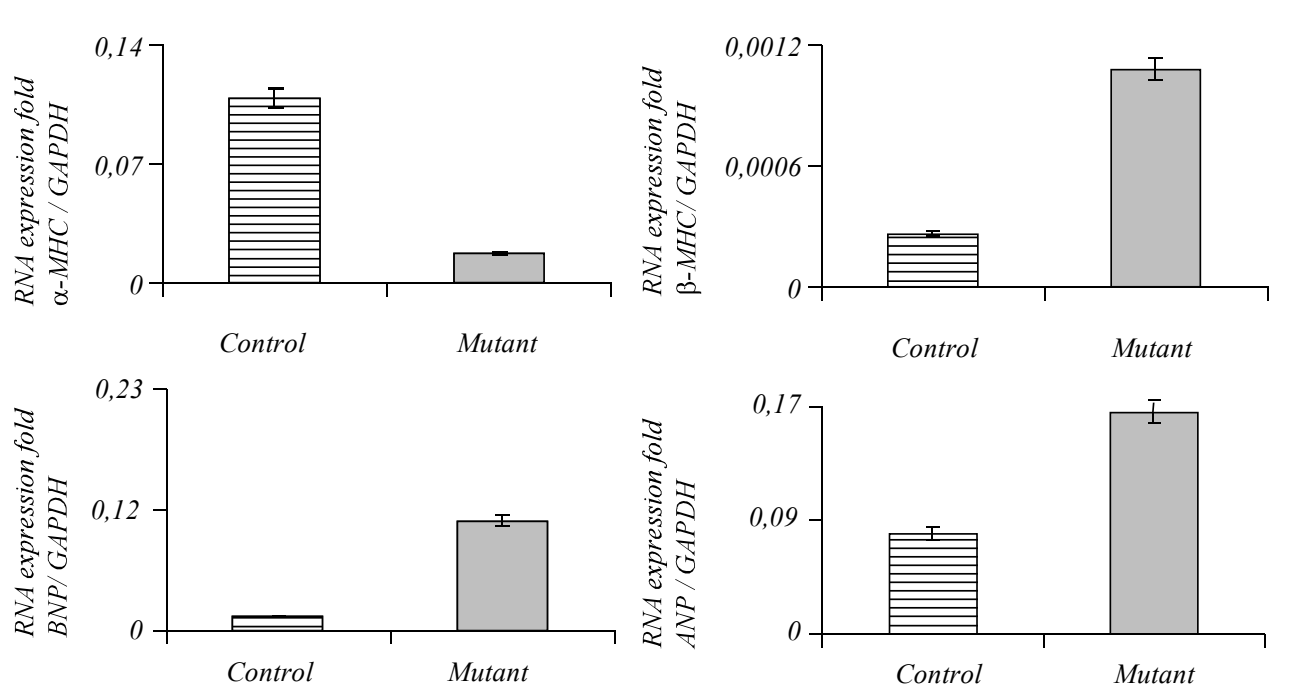

Fig. 4. The hypertrophic response genes expression in $\beta$ catenin haploinsufficient mice at 3 month of age. Each group consists of 2 mice
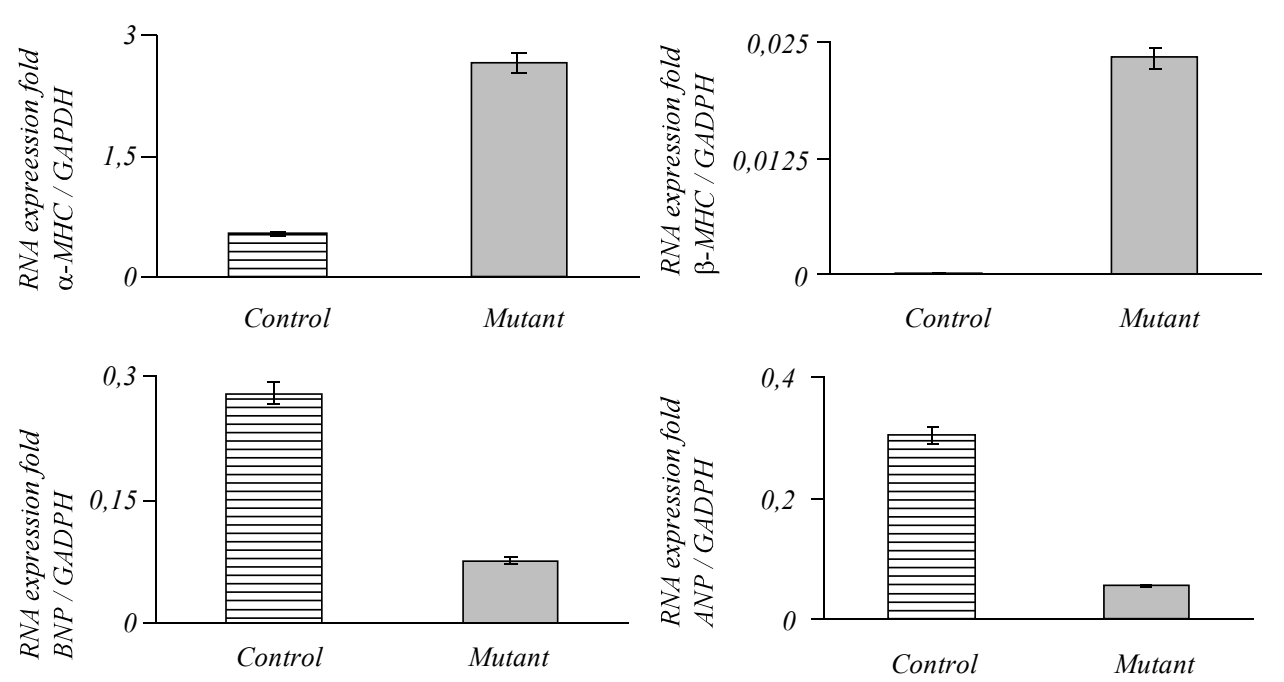

Fig. 5. The hypertrophic response genes expression in $\beta$ catenin haploinsufficient mice at 6 month of age. Each group consists of 2 mice

genes) in the adult heart of experimental animals under prolonged exercises (training) seems to be logical.

In our experiment we also registered some foetal genes program upregulation in age-dependent manner. In 6-month-old animals we observed that $A N P$ and $B N P$ genes were downregulated but both $\beta$ - and $\alpha-M H C$ genes were overexpressed comparing with control animals. Such processes are not typical for adult mature heart, and should be the sign of some abnormality in mutant mice especially given that young organism was growing actively. We can speculate that some compensatory effects were involved in ageing heart adaptation under $\beta$-catenin haploinsufficiency conditions. It was shown by another group of authors [21] that ablation of $\beta$-catenin and plakoglobin in adult heart leads to hyperthrophy and lethality. Authors made a suggestion that these effects are mediated by WNT/ $\beta$-catenin-independent unspecified compensation which is supported by the evidence obtained with other models usage $[7,35]$.

Noteworthy also is the hypothesis that although $A N P$ and $B N P$ are marker genes of hypertropic response widely used in clinics their function in cardiomyocytes under hypertrophic stimuli is rather compensatory [36, 37]. Their expression in cardiomyocytes is responsive to physical and/or chemical hypertrophic stimuli and contributes to numerous different physiological processes regulation. In particular they are known to decrease apoptosis and fibrosis as well as protein and DNA synthesis levels in cardiomyocytes developing hypertrophy. The upregulation of foetal genes in the $\beta$-catenin haploinsufficient cardiomyocytes comparing to control lit- 
termates at 1 and 3 months age indicates that heart of these animals is not able to cope with the needs of actively growing organisms. The most obvious reason for this is the inability of experimental mice heart tissue to sustain the necessary level of basal Wnt-signaling activity due to one $\beta$-catenin gene allele ablation. Further investigation suggests that 6 months old myocardium has lower levels of $A N P$ and $B N P$ comparing with control animals of the same age indicating that aging engages some compensatory mechanisms controlled by different signaling cascades.

We suggest that cardiospecific $\beta$-catenin deficiency leads to failure of signaling networks in adult heart followed by heart violation with ageing. To further clarify this question we are going to analyze older age group ( 9 month). Also the kinetic of signaling activity of $\beta$-catenin under $\beta$-catenin haploinsufficiency at different ageing groups of animals needs to be studied in the future.

Conclusions. Embryonically induced $\beta$-catenin haploinsufficiency in heart doesn't lead to lethality or to morphological malformations and heart tissue fibrosis. But it contributes to postnatal heart development via upregulation of hypertrophic response gene in agedependent manner.

Acknowledgements. We thank Dr. Glenn L. Radice from Jefferson Medical College (Philadelphia, USA) for providing the $\alpha$-MHC-Cre and $\beta$-cateninf ${ }^{\text {lox/lox }}$ animals.

О. Л. Пальчевська, В. В. Балачький, А. О. Андрєєва, Л. Л. Мацевич, О. О. Півень, Л. Л. Лукаш

Ембріональна делеція одного алеля гена $\beta$-катеніну спричиняє затримку постнатального розвитку міокарда та порушення експресії фетальних генів

Резюме

Роль білка $\beta$-катеніну у перебудовах міокарду і розвитку його гіпертрофії на сьогодні є предметом численних $i$ часто суперечливих досліджень. Мета. Вивчити вплив кардіоспецицфічного зниження рівня експресї гена $\beta$-катеніну на розвиток серця на моделі умовно-нокаутних тварин. Методи. Використано стандартні гістологічні (гематоксилін-еозинове $i$ трихромне забарвлення) та зворотно-транскриптазну ПЛР у реальному часі. Результати. Проаналізовано вплив нестачі одного алеля гена $\beta$-катеніну на постнатальний розвиток і формування дорослого органа. Відмічено зростання рівня експресії фетальних генів у тварин усіх вікових груп за умови нестачі одного алеля гена $\beta$-катеніну. Висновки. Отримані дані свідчать про те, щзо досліджуваний нами стан спричиняє затримку розвитку і росту дорослого серия, проте без жодних ознак морфологічних відхилень порівняно з контрольними тваринами відповідних вікових груп.
Ключові слова: розвиток серчя, $\beta$-катенін, Wnt-сигналінг, перебудова серия, гіпертрофічна відповідь.

О. Л. Пальчевська, В. В. Балацьький, А. О. Андрєєва, Л. Л. Мацевич, О. О. Півень, Л. Л. Лукаш

Эмбриональная делеция одного аллеля гена $\beta$-катенина вызывает задержку постнатального развития миокарда и нарушения экспрессии фетальных генов

Резюме

Роль белка $\beta$-катенина в перестройках миокарда и развитии его гипертрофии на сегодняшний день является предметом упорных и зачастую противоречивых исследований. Цель. Изучить влияние кардиоспецифического снижения уровня экспрессии гена $\beta$ катенина на развитие сердияа на модели условно-нокаутных животных. Методы. Использованы стандартные гистологические методы (гематоксилин-эозиновое и трихромное окрашивание) $и$ обратно-транскриптазную ПЦР в реальном времени. Результаты. Проанализировано влияние недостатка одного аллеля гена $\beta$-катенина на постнатальное развитие и формирование взрослого органа. Отмечено повышение уровня экспрессии фетальных генов во всех возрастных группах животных при условии недостатка одного аллеля гена $\beta$-катенина. Выводы. Полученные данные показывают, что исследованное нами состояние вызывает задержку развития и роста взрослого сердиа, впрочем без каких-либо признаков морфологических отклонений по сравнению с контрольными животными соответствующих возрастных груnп.

Ключевые слова: развитие сердиа, $\beta$-катенин, Wnt-сигналлинг, перестройка сердия, гипертрофический ответ.

\section{REFERENCES}

1. Nadal-Ginard B., Kajstura J., Leri A., Anversa P. Myocyte death, growth, and regeneration in cardiac hypertrophy and failure // Circ. Res.-2003.-92, N 2.-P. 139-150.

2. Brade T., Manner J., Kuhl M. The role of Wnt signalling in cardiac development and tissue remodeling in the mature heart // Cardiovasc. Res.-2006.-72, N 2.-P. 198-209.

3. Malekar P., Hagenmueller M., Anyanwu A., Buss S., Streit M. R., Weiss C. S., WolfD., Riffel J., Bauer A., Katus H. A., Hardt S. E. Wnt signaling is critical for maladaptive cardiac hypertrophy and accelerates myocardial remodeling // Hypertension.2010.-55, N 4.-P. 939-945.

4. Grigoryan T., Wend P., Klaus A., Birchmeier W. Deciphering the function of canonical Wnt signals in development and disease: Conditional loss- and gain-of-function mutations of beta-catenin in mice // Genes Dev.-2008.-22, N17.-P. 2308-2341.

5. Lickert H., Kutsch S., Kanzler B., Tamai Y., Taketo M. M., Kemler $R$. Formation of multiple hearts in mice following deletion of beta-catenin in the embryonic endoderm // Dev. Cell.-2002.-3, N 2.-P. 171-181.

6. Cadigan K. M., Peifer M. Wnt signaling from development to disease: insights from model systems // Cold Spring Harb. Perspect. Biol.-2009.-1, N 2.-a002881.

7. Bergmann $M$. W. WNT signaling in adult hypertrophy and remodeling: lessons learned from cardiac development // Circ. Res.2010.-107, N 10.-P. 1198-1208.

8. Gordon M. D., Nusse R. Wnt signaling: multiple pathways, multiple receptors, and multiple transcription factors // J. Biol. Chem.-2006.-281, N 32.-P. 22429-22433. 
9. Rao T. P., Kuhl M. An updated overview on Wnt signaling pathways: a prelude for more // Circ. Res.-2010.-106, N 12.P. 1798-1806.

10. Archbold H. C., Yang Y. X., Chen L., Cadigan K. M. How do they do Wnt they do?: regulation of transcription by the Wnt/ $\beta$-catenin pathway // Acta. Physiol. (Oxf).-2012.-204, N 1.-P. 74-109.

11. Nusse R. Wnt signaling and stem cell control// Cell Res.-2008.18, N 5.-P. 523-527.

12. Klaus A., Muller M., Schulz H., Saga Y., Martin J. F., Birchmeier $W$. Wnt/ $\beta$-catenin and Bmp signals control distinct sets of transcription factors in cardiac progenitor cells // Proc. Natl Acad. Sci. USA.-2012.-109, N 27.-P. 10921-10926.

13. Gessert S., Kuhl M. The multiple phases and faces of Wnt signaling during cardiac differentiation and development // Circ. Res.-2010.-107, N 2.-P. 186-199.

14. Haegel H., Larue L., Ohsugi M., Fedorov L., Herrenknecht K., Kemler $R$. Lack of beta-catenin affects mouse development at gastrulation // Development.-1995.-121, N 11.-P. 3529-3537.

15. Huelsken J., Vogel R., Brinkmann V., Erdmann B., Birchmeier $C$., Birchmeier $W$. Requirement for beta-catenin in anteriorposterior axis formation in mice // J. Cell. Biol.-2000.-148, N 3.-P. 567-578.

16. Lickert H., Kutsch S., Kanzler B., Tamai Y., Taketo M. M., Kemler $R$. Formation of multiple hearts in mice following deletion of beta-catenin in the embryonic endoderm // Dev. Cell.-2002.-3, N 2.-P. 171-181.

17. Piven O. O., Kostetskii I. E., Macewicz L. L., Kolomijec Y. M., Radice G. L., Lukash L. L. Requirement for N-cadherin-catenin complex in heart development // Exp. Biol. Med. (Maywood).2011.-236, N 7.-P. 816-822.

18. Qu J., Zhou J., Yi X. P., Dong B., Zheng H., Miller L. M., Wang $X$., Schneider M. D., Li F. Cardiac-specific haploinsufficiency of beta-catenin attenuates cardiac hypertrophy but enhances fetal gene expression in response to aortic constriction // J. Mol. Cell. Cardiol.-2007.-43, N 3. P. 319-326.

19. Butz S., Stappert J., Weissig H., Kemler R. Plakoglobin and beta-catenin: distinct but closely related // Science.-1992.-257, N 5073.-P. 1142-1144.

20. Zhou J., Qu J., Yi X. P., Graber K., Huber L., Wang X., Gerdes A. M., LiF. Upregulation of gamma-catenin compensates for the loss of beta-catenin in adult cardiomyocytes // Am. J. Physiol. Heart Circ. Physiol.-2007.-292, N 1.-H270-H276.

21. Swope D., Cheng L., Gao E., Li J., Radice G. L. Loss of cadherin-binding proteins, $\beta$-catenin and plakoglobin, in the heart leads to gap junction remodelling and arrhythmogenesis // Mol. Cell. Biol.-2012.-32, N 6.-P. 1056-1067.

22. Haq S., Michael A., Andreucci M., Bhattacharya K., Dotto P. Walters B., Woodgett J., Kilter H., Force T. Stabilization of beta-catenin by a Wnt-independent mechanism regulates cardiomyocyte growth // Proc. Natl Acad. Sci. USA.-2003.-100, N 8.P. 4610-4615.

23. Liu X., Rubin J. S., Kimmel A. R. Rapid, Wnt-induced changes in GSK3beta associations that regulate beta-catenin stabilization are mediated by Galpha proteins // Curr. Biol.-2005.-15, N 22.-P. 1989-1997.

24. Chen X., Shevtsov S. P., Hsich E., Cui L., Haq S., Aronovitz M., Kerkela R., Molkentin J. D., Liao R., Salomon R. N., Petten R., Force $T$. The beta-catenin/T-cell factor/lymphocyte enhancer factor signaling pathway is required for normal and stress induced cardiac hypertrophy // Mol. Cell. Biol.-2006.-26, N 12.P. 4462-4473.
25. Hirschy A., Croquelois A., Perriard E., Schoenauer R., Agarkova I., Hoerstrup S. P., Taketo M. M., Pedrazzini T., Perriard J. $C$., Ehler $E$. Stabilised beta-catenin in postnatal ventricular myocardium leads to dilated cardiomyopathy and premature death // Basic Res. Cardiol.-2010.-105, N 5.-P. 597-608.

26. Hahn J. Y., Cho H. J., Bae J. W., Yuk H. S., Kim K. I., Park K. W., Koo B. K., Chae I. H., Shin C. S., Oh B. H., Choi Y. S., Park Y. B., Kim H. S. Beta-catenin overexpression reduces myocardial infarct size through differential effects on cardiomyocytes and cardiac fibroblasts // J. Biol. Chem.-2006.-281, N 41.-P. 3097930989.

27. Baurand A., Zelarayan L., Betney R., Gehrke C., Dunger S., Noack C., Busjahn A., Huelsken J., Taketo M. M., Birchmeier W., Dietz $R$., Bergmann $M$. W. Beta-catenin downregulation is required for adaptive cardiac remodeling // Circ. Res.-2007.-100, N 9.P. 1353-1362.

28. Lyons G. E., Schiaffino S., Sassoon D., Barton P., Buckingham $M$. Developmental regulation of myosin gene expression in mouse cardiac muscle // J. Cell. Biol.-1990.-111, N 6, Pt 1.-P. $2427-$ 2436.

29. Agah R., Frenkel P. A., French B. A., Michael L. H., Overbeek P. A., Schneider M. D. Gene recombination in postmitotic cells. Targeted expression of Cre recombinase provokes cardiacrestricted, site-specific rearrangement in adult ventricular muscle in vivo // J. Clin. Invest.-1997.-100, N 1.-P. 169-179.

30. Nagy A., Gertsenstein M., Vintersten K., Behringer R. Manipulating the mouse embryo: A laboratory manual.-New York: Cold Spring Harbor Lab. Press, 2003.-234 p.

31. Palermo J., Gulick J., Colbert M., Fewell J., Robbins J. Transgenic remodeling of the contractile apparatus in the mammalian heart // Circ. Res.-1996.-78, N 3.-P. 504-509.

32. Izumo S., Lompre A. M., Matsuoka R., Koren G., Schwartz K., Nadal-Ginard B., Mahdavi $V$. Myosin heavy chain messenger RNA and protein isoform transitions during cardiachypertrophy. Interaction between hemodynamic and thyroid hormoneinduced signals // J. Clin. Invest.-1987.-79, N 3.-P. 970-977.

33. Besse S., Assayag P., Delcayre C., Carre F., Cheav S. L., Lecarpentier $Y$., Swynghedauw B. Normal and hypertrophied senescent rat heart:mechanical and molecular characteristics // Am. J. Physiol.-1993.-265, N 1 Pt 2.-H183-H190.

34. Lowes B. D., Minobe W., Abraham W. T., Rizeq M. N., Bohlmeyer T. J., Quaife R. A., Roden R. L., Dutcher D. L., Robertson A. D., Voelkel N. F., Badesch D. B., Groves B. M., Gilbert E. M., Bristow $M$. R. Changes in gene expression in the intact human heart. Downregulation of alpha-myosin heavy chain in hypertrophied, failing ventricular myocardium // J. Clin. Invest.-1997.100, N 9.-P. 2315-2324.

35. Li J., Swope D., Raess N., Cheng L., Muller E. J., Radice G. L. Cardiac tissue-restricted deletion of plakoglobin results in progressive cardiomyopathy and activation of $\{$ beta $\}$-catenin signaling // Mol. Cell. Biol.-2011.-31, N 6.-P. 1134-1144.

36. Vanderheyden M., Bartunek J., Goethals M. Brain and other natriuretic peptides: molecular aspects // Eur. J. Heart Fail.-2004.6, N 3.-P. 261-268.

37. Tamura N., Ogawa Y., Chusho H., Nakamura K., Nakao K., Suda M., Kasahara M., Hashimoto R., Katsuura G., Mukoyama M., Itoh H., Saito Y., Tanaka I., Otani H., Katsuki M. Cardiac fibrosis in mice lacking brain natriuretic peptide // Proc. Natl Acad. Sci. USA.-2000.-97, N 8.-P. 4239-4244. 